\title{
Study on the Transfer Payment Policy about the Low-Income Housing in China
}

\author{
Qun Gao \\ College of Economic Management, Nanjing Institute of Industry Technology, Nanjing 210046, China \\ E-mail: g.qun@163.com
}

The research is supported by the project of the Jiangsu Provincial College Philosophical and Social Science Fund (No. 09SJD790026). (Sponsoring information)

\begin{abstract}
The current low-income housing system in China is the security system giving priority to the low-rent housing and the economically affordable housing. The housing security system includes the systems and measures that the government uses the national and social power to provide the basic housing for those difficult housing groups by the transfer payment policy, and realize the equalization of the public service in the domain of real estate.
\end{abstract}

Keywords: Low-income housing, Transfer payment, Real estate, Equalization

The low-income housing system means a series of system giving priority to the transfer payment system, and the concrete systems includes that the government provides the basic living houses for those low-income families, and provides the low-rent house for those lowest-income families by the power from the country, the local government, and the society, and provides the economically affordable house for low-income families, and provides the price-limit house and the commodity house for the middle and high-income families. The main target of the transfer payment system is the equalization of public services, and the equalization of the real estate means the fair sharing of the special public commodity, i.e. the real estate, which also could help the harmonious development of the real estate economy. Since 2005, the housing policy of China had begun transforming from the market housing to the low-income housing, to solve the housing difficulty of low-income families. In the August of 2007, Certain Opinions about Solving the Housing Difficult Problems of Urban Low-income Families of the State Council of China indicated that the low-income housing policy of China went to be perfected.

\section{The current transfer payment policy of China}

The finance transfer payment system is based on the tax distribution system of 1994, and it is composed by three parts, i.e. the tax rebates, the general transfer payment, and the special transfer payment, and it is the transfer payment system with Chinese characteristics giving priority to the transfer payment from the central government to the local governments.

\subsection{Tax rebates}

Tax rebates is the main form of the finance transfer payment of China, and it is the important source of the local finance incomes, so whether the tax rebates is designed reasonably or not determines the reasonability of the whole system. But the tax rebates is still distributed based the base to maintain the local vested interests, and it embodies the policy that inclines to those regions with strong income ability, and it maintains the vested interests of rich regions, and runs counter to the intention reducing the gap among regions. In addition, though the tax rebates belongs to the central finance income on paper, but the local finance could determine these capitals finally.

\subsection{General transfer payment}

The general transfer payment is the subsidy payout which is arranged by the central finance for local finances to compensate the financial gap of those regions with weak financial strengths. The general transfer payment is the important measure to reduce the financial gap among regions, and it is the main part of the finance transfer payment, and mainly includes many forms such as the common transfer payment, the adjusted wage transfer payment, the national region transfer payment, the rural taxation expenses reform transfer payment, and the year-end balance finance subsidy.

\subsection{Special transfer payment}

The special transfer payment is the subsidy capitals established by the central fiancé to realize special macro policies 
and development strategic targets, and it is mainly used in various public service domains about the people's livelihood. And local finances should use the capitals according to the regulated purpose.

\section{The transfer payment of the government financial capitals}

Financial capital is one of the main capital sources of the low-income housing construction. In past local financial budget, the low-income housing construction capitals have not been arranged, and at present, the space to pay the low-income housing capitals in the local financial budge which is originally intense is very limited. For the west regions with difficult financial income, the central government could support the local governments by the forms such as the budgetary investment subsidy and the special subsidy capitals of financial low-rent housing. In addition, the property tax can be collected in the whole country, and part of the taxation could be used for the construction capitals of the low-income housing, which is deserved to be explored.

\section{The transfer payment of the added-incomes of housing fund}

According to the "Temporal Methods of the National Social Security Fund Investment Management" of the Ministry of Finance and the Ministry of Labor and Social Security, all net incomes of the social security fund should be brought into the social security fund which should be distributed and invested according to relative regulations of China. The "Methods" regulated that the housing fund was the "long-term housing savings fund", so the housing fund is the guarantee capitals which are specially used for solving the employees' housing problem, with the characteristics such as the specificity, the mutual assistance, and the security. These characteristics of the housing fund also belong to the content of social securities. The housing fund system should realize the mutual benefit, the mutual assistance, and the mutual association among subscribers, i.e. the added income of the housing fund except for the loan risk reserve and the relative management charges is used for the construction of low-rent houses. Since 1998, the construction capitals from the added income of the housing fund have achieved about 10 billions Yuan, which is one form of the mutual assistance, and it could not only effectively solve the problem of difficult housing of low-income families, and accord with the essential attributes of the housing fund such as the mutual assistance and the security, but also embody the intention that China pushed the housing fund system, and promote the health development of the housing fund system.

The added income of the housing fund means the difference between the operation income and the operation payout of the housing fund. The operation income includes (1) the interest income of the personal housing loans of the housing fund, (2) the income of the bank credit, and (3) the interest income of purchasing the national debts. The operation payout mainly includes (1) the agent fees of banks, (2) the deposit interest of the employees' personal housing fund, and (3) other relative management charges. That is to say, the added income of the housing fund is composed by the deposit interest and the interest different between loans and deposits (i.e. the interest difference between the housing fund deposits and loans). In fact, the added income of the housing fund is generated in the process that the housing fund management center utilizes employees' personal housing funds to satisfy subscribers' demands of purchasing houses and adding values under the support of national policy, and implements many added value activities such as depositing, loaning, and purchasing national debts.

\section{The transfer payment of the land-transferring fees}

Land is the basic resource for the human being to survive. The establishment of the land transfer system and the obtainment and distribution of the land transfer income are the basic guarantee for human being to live and develop. The formation of the land price accords with the economic development, the development course of city, and the durative of the land development, and only in this way, the security function of land could be exerted fully. As the important strategic resource of the country, the land is used for the country to obtain the durative profit by the land transfer, which is used for the public establishment service and the public management, and the construction of the low-rent houses. In the Economic Housing Application Procedures of China, the construction lands of the economic houses are provided by the form of administrative allocation, and brought into the yearly land supply plan of the current year, so the land cost of the economic housing construction is almost zero. At the same time, local governments are exempted from various administrative fees and governmental funds of the urban basic establishment expenses for the economic housing projects.

The central government has required local governments to use more land transfer incomes in the housing construction of the low-rent houses and other security houses by the land income transfer payment, which could further solve the difficult housing for middle and low-income families in the economic regression. The proportion of the low-rent housing guarantee capitals in the new income of land transfer should exceed $10 \%$, and local governments could properly enhance this proportion according to the actual situations. The sharing of land income is the biggest livelihood, and to realize this sharing, the land price will certainly rise with the maturing of the regions and the land price in the mature regions only ascend and present the tendency of increasing values. In 2009, the 
income of national funds was 1833.504 billion Yuan, which equaled to $26.8 \%$ of the national finance income in the same period. In the income, the most was the state-owned land sale revenue of use-right. In this year, the income of national land transfer was 1423.97 billion Yuan, $77.7 \%$ of the income of national funds, and the contribution ratio of the land transfer income to the national finance income was about $21 \%$. The central government and local governments increased the public finance income by obtaining the lands, and improved the difficult housing of low-income families by the transfer payment.

\section{The attempt that enterprises use their own lands to develop the economically affordable houses}

Because the construction of the low-income housing belongs to the governmental function, and the construction scale is larger, the "land finance" of the government reduces more, and local governments could let some big enterprises with lands to participate in the low-income housing construction, so some governmental functions could be shared by enterprises, which could not only reduce the burden of the government, but also correspondingly reduce the instant loss of the "land finance". In this way, both the government and the enterprise could obtain their own profits, and at the same time, because the new competitive subject, i.e. the industrial enterprises with lands, will occur in the commercial housing development market, that means the house price may descend properly. According to relative reports, many big enterprises in Shanghai have large numerous of lands, and the positions of these lands are better than the lands from the governments. It is obvious that these enterprises would use their lands for the commercial housing development and construction, but that was forbidden by the state. On the contrary, without special policies, these enterprises will not use their own lands for the commercial housing development and construction. Though the government has attracted many big enterprises to use their own lands to participate in the low-income housing construction, the policies may be changed. According to the "The Low-income Housing Construction Land Supply Management Implementation Methods of Shanghai", "if the enterprises voluntarily use their lands to apply and participate in the construction of low-income house, the baseline proportion of the low-income housing construction is 50\%". That is to say, the other $50 \%$ of lands could be allowed to construct the commercial houses. If this policy could be implemented, many enterprises would actively participate in the construction of the low-income house.

\section{Horizontal transfer payment among governments}

In the practice, the horizontal transfer payment of finance has not occurred in the low-income housing among same-level governments. The transfer payment among governments is mainly to balance the gap of the government income because of different geographical environments or economic development levels, and ensure the local governments could effectively provide housing guarantee for difficult families according to the uniform standard of the state. Generally, the regions with developed economy and rich finance could transfer the finance to the poor regions, for supporting other regions each other, reducing the regional gap, balancing the finance, assisting the society, and supporting the minority. The capitals come from regions with rich finance, and the capital transfer is direct, transparent, and highly effective. With the encouragement of the central government, a non-formula and non-institutionalized transfer payment occurs among provinces and regions.

In addition, the housing funds of different regions are extremely unbalanced, and the management of the housing funds in developed regions is reasonable, but the usably idle funds are less, and on the contrary, the housing funds in middle and west regions are rich, but the management is not standard relatively. The total idle housing funds of China are about one hundred or two hundred billions Yuan and the funds among different regions are not balanced, and if the uniform housing fund platform could be established in China, the funds in the rich regions could flow to those poor regions, and the low-income housing problem could be solved better.

\section{Main problems and countermeasures}

\subsection{The transfer payment system of the low-income housing is not perfect, and the implementation power is not} sufficient

At present, there are not complete and systematic implementation methods about the finance capitals, land transfer, financial support, and trans-regional utilization of housing fund of the low-income housing construction, especially the problem how to carry out the capitals lacks in perfect measures. When the planning index has not been confirmed, part local governments negatively implement the financial payouts, which largely reduced the construction of low-rent houses.

The central government should require local governments to institute the low-income housing policies according to their local institutions for low-income families, and strengthen the supervision to local governments for the implementation of policies. At the same time, the construction of laws and regulations about the low-income housing should be quickened, and the local governments' responsibilities about the residence right should be 
confirmed by the legislation, and the subject and object of the low-income housing should have relative laws and regulations to abide by.

\subsection{The construction capital source of the low-income housing is deficient, and the proportion is lower}

According to the "Urban Low-cost Housing Management Practices of China", the construction capitals of low-rent house should give priority to the public budget capitals of finance, but only a few cities establish the finance capitals supply plans from the system, and most cities depend on the added incomes of housing funds and the surplus of the low-income housing sales to collect the construction capitals of low-rent houses. This capital proportion is lower, and not stable, and the subsequent capitals could be guaranteed.

Therefore, the central government and the local governments must strengthen the finance capital supply plan of the low-rent houses, fully and reasonably utilize the added income of housing fund, enhance the proportion of the land transfer income in the low-rent housing construction capitals, actively exert the social power, and collect the construction capitals of low-income houses from multiple channels. At the same time, the investment subsidy of the central budget and the special subsidy capitals of the central financial low-rent house should incline to the difficult regions in the middle and west of China.

\section{References}

Gao, Qun. (2006). Brief of the Development Prospect of Traveling Property. Construction Economy. No.7.

Niu, Fengrui \& Li, Jingguo. (2008). Development Report of Chinese Real Estate. Beijing: Social Sciences Academic Press.

Qiao, Baoyun, Fan, Jianyong \& Peng, Jiming. (2006). Government Transfer Payment and Local Finance Endeavor. Management World. No.3.

Yin, Heng, Kang, Linlin \& Wang, Lijuan. (2007). Financial Equalization Effect of the Government Transfer Payment: Research Based on China County-level Data. Management World. No.1.

Zeng, Qianfeng. (2010). Causes and Countermeasures of the Financial Risks in Chinese Real Estate. Business China. No.2. 